\title{
Translation of Anatole France's L'Étui de nacre in Russia: Reception and Perception
}

\author{
NATALIA NIKITINA \\ NATALIA TULIAKOVA
}

\begin{abstract}
The paper analyzes and compares the numerous translations of L'Étui de nacre by Anatole France into Russian. The undertaken research aims at establishing the tendencies in the long series of translations, taking into account the possible reasons for the translators' long-lasting interest in the text.

We first analyze the translational theories of the time and highlight their evolution during the first half of the $20^{\text {th }}$ century. Then, we suggest an analysis of France's cycle, and consider the motives behind its appeal to the translators. Finally, we compare the strategies chosen by the translators and the way they may affect the perception of the text. We argue that the flow of translations may be explained by the complexity of France's text, which has resulted in a constant search for a perfect translation. The complexity comprised both linguistic difficulties, such as France's balance of natural speech and elevated objects of description, and extralinguistic hurdles, for instance, the abundance of realias belonging to different epochs and countries. It is obvious that translations done in different years from 1890 to 1959 reflect the development of translation theory and also the political and social changes which Russia underwent during this period. Another conclusion that we are coming to is that the existing translations tend to demonstrate a significant decrease in ambiguity, inherent in France's cycle.
\end{abstract}

Keywords: literary translation; translation theories; French-Russian literary connections; Anatole France

\section{Introduction}

The fin de siècle in Russia was characterized by the heyday not only in domestic literature but also in literary translation. Anatole France's cycle L'Étui de nacre, which initially consisted of 16 short stories, was barely an exception. Rather, it enjoyed an unprecedented enthusiasm of Russian translators of different rank. Some of the cycle parts were translated up to sixteen times in about sixty years, and it was not unusual for a new translation to appear every half a year. 
NIKITINA, TULIAKOVA

It is worth mentioning, though, that the translations did not come out regularly, on the contrary, there have been three peaks of interest: in the first decade of the twentieth century, in the 1920s and in the 1950s. This suggests that literary tastes, language norms and stylistic conventions underwent significant alterations between the periods. The theory of translation itself was being developed during these decades, therefore the first translations were of a more intuitive nature, whereas the ones in the middle of the twentieth century could rely on more solid theoretical foundations. Besides, the regime and ideology were completely transformed and the translations could not but reflect these changes.

We will start with an overview of the translations of L'Étui de nacre and possible grounds for the obsession with the cycle and particular stories. It is essential to look into the translational theories of the time and understand the attitude to the process of translation on the whole. The next stage of research will involve suggesting a classification of challenges which the translators faced during their work through comparing the original text with the translations and identifying the parts which tended to be translated in a different way. Then we will be able to generalize and classify the chosen strategies and their correlation to linguistic or extralinguistic reasons. Finally, we will evaluate the translations of the most popular parts of L'Étui de nacre, Le Procurateur de Judée and Le Jongleur de Notre-Dame and illustrate how translators' techniques could alter the overall message of the original.

\section{L'Étui de Nacre and translational practices in Russia and the USSR}

France's cycle received international acclaim and was translated into many languages - English, ${ }^{1}$ German, ${ }^{2}$ Hungarian, ${ }^{3}$ Portuguese, ${ }^{4}$ Japanese, ${ }^{5}$ Spanish, ${ }^{6}$ Check, ${ }^{7}$ Italian, ${ }^{8}$ and others. It is notable that the Russian language was among

1 France, A. Tales From a Mother-of-Pearl Casket. NY: George H. Richmond and Co, 1896; France, A. Mother of Pearl. London; New York: John Lane Company, 1917.

2 France, A. Die Perlmutterdose. Novellen. München: Musarion Verlag, 1920.

3 France, A. Gyöngyház szelence: novellák. Budapest: Kultúra, 1921.

4 France, A. O procurador da Judéa: Balthasar. Crainquebille. Rio de Janeiro: Castilho, 1929.

5 France, A. Raden no tebako. Tokyo: Hakusuisha, 1939.

6 France, A. El estuche de nácar. Agentina: Tor, 1949.

France, A. Perletová skř́nka. Praha: NV, 1956.

8 France, A. l procuratore della Giudea. Palermo: Sellerio, 1980. 
the ones into which France's oeuvre on the whole and the cycle in particular were translated very promptly.

The peculiarities of the cycle translation into Russian are partly connected with the history of the text. Many stories of the cycle were initially published in French daily papers (Le Temps, Le Gaulois, and others); others were originally chapters of the novel Les Autels de la peur (1884), which France published only once in the French Journal des Débats. In 1892 the cycle came out in its entirety, and in 1922 the new version with 17 stories appeared, which is now used at the standard one. The first translations of separate stories came out in Russian periodicals in as early as 1890, while the original was published in French newspapers. Surprisingly, the translation of Les Messe des ombres appeared in the Russian newspaper Русские ведомости ('Russian News Bulletin') earlier (25/12/1890) than the original was circulated by Le Temps (26/12/1890). Translations of other stories date back to 1899 , when the number of translated texts gradually increased.

Surprisingly, though, the long history as well as the number and variety of different translations of the cycle have not attracted the attention of translation scholars and theorists. The present article is based on the first attempt to systematize and analyze the existing bulk of translations in order to prepare an academic publication of L'Étui de nacre for the modern Russian reader.

Before embarking on the analysis of the cycle's translations it is necessary to briefly outline the state of affairs in the field of literary translation in Russia, which commenced to be an object of theoretical discussion and practical concern in the eighteenth century when the bulk of the "old" literature was translated along with the "new" (Fedorov 1983: 69-76). As most educated people had profound knowledge of European languages, translators felt somewhat free and perceived their texts as an opportunity to express themselves, not seeing the translation as a substitute for the original text (Tretyakova 2012: 72-73).

At the end of the nineteenth century the reading audience swelled in comparison with the early nineteenth century, while the number of people who could read in the original decreased. That is why translation began to exist as a substitute for the original. It is natural that due to the fast pace and massive bulk of translations, short literary forms attracted the attention of translators, the number of translated short stories published being high, especially from French (Fedorov 1968: 85).

The translation practices of the late nineteenth - early twentieth centuries were significantly altered in comparison with the previous epoch and were driven by the opposite tendencies. Despite the experience gained in the literary translation since Romanticism, the general level of translation suffered a lot 
NIKITINA, TULIAKOVA

(Fedorov 1968: 86). Moreover, the idea that translation should be a precise reflection of the spirit (or the world described) rather than literal repetition in a different language was firmly established in the minds of translators. This belief brought about many alterations in the texts of translations, abundance of Russian realias (Fedorov 1968: 88) in description of European life, which would allow the reader to perceive the text as belonging to their own culture.

Another worrying tendency was the enlarged number of professional translators willing to earn their living by quickly saturating the need for foreign literature (Hofmann 1910: 401). For example, one of France's translators, Zinovy L'vovsky, could translate from English, French, German, Norwegian, the result being below the standard. The huge amount of badly translated literature filled the market (Fedorov 1968: 84). Translators knew the languages poorly and made frequent factual and stylistic mistakes, thus the Russian versions were very loosely connected with the originals. At the same time, this tendency could be combined with literal translations within one text (Fedorov 1968: 87; Tretyakova 2012: 273).

The state of affairs was also connected with the genre of original texts. The translation theories were mainly concerned with the challenges which translators faced while working with poetry. These theories were developed by those who wrote fiction in their own language (Afanasy Fet, Fedor Sologub, Valery Bryusov, Innokenty Annensky, and others) and poetic translations might have served as a kind of experiment. Prose, being less structured, did not cause as much theoretical controversy and public discussion; however, prosaic translations were heavily criticized in periodicals for their low quality.

The acclaim of France's stories among Russian translators could be compared only to the popularity of major literary works or verses of outstanding European poets. The flood of translations can be accounted for by the popularity of foreign literature on the whole and French fiction in particular. Altogether, one should bear in mind a special interest of the Russian public in the French writer who was regarded as the most notable contemporary French literary figure by many distinguished authors (Voloshin 1999: 85, Kuzmin 1989: 39, Zamyatin 1988: 393). It is an established fact that the first story of L'Étui de nacre, Le Procurateur de Judée, had a serious impact on the image of Pontius Pilate in Mikhail Bulgakov's renowned Macmep u Mapzapuma ('The Master and Margarita') (Sokolov 1996).

In Russia, L'Étui de nacre appealed to translators of various ranks, including famous ones, like Zinaida Vengerova (France 1906b), and littleknown (France 1907), as well anonymous ones (France 1901). France's text drew attention of such prominent Russian writers as Aleksander Kuprin and Benedikt Livshits. The level of translations varied to a great extent: from the 
ridiculous "old-Russian" version by L'vovsky and stylistic embellishments by An. Annenskiy through careful editing by Livshits to a rude and abrupt version by Nina Yakovleva.

The early translations were generally disapproved of by reviewers and critics, and the general opinion was that France's text was impaired a lot. Victor Hofmann, a then famous poet, translator and reviewer, claimed that France was the writer "who suffered most from low-culture translations... Probably, no other translation needs such pedantic awe and critical love as translation of this elegant apologist of scepticism, this powerful resurrector of various epochs and this sublime reporter and psychologist of the modern time" (Hofmann 1910: 409). The same idea was expressed not once by Alexander Bryusov, a younger brother of Valery Bryusov, poet, literary critic and prominent historian (Bryusov 1906: 68; Bryusov 1907: 54). France's admirers of the beginning of the twentieth century emphasised the elegance of his style, and the critics, who knew French, shared this approach, censuring the translators for the failure to render the beauty of the French writer's language.

After the October Revolution, France did not lose any of his popularity. This fact could mostly have been due to his political views, as well as his denunciation of the Church. The focus of public interest, however, shifted from his short stories to novels, which were frequently published during the Soviet period. Along with this deviation, stylistic debate became less active, as editors and translators concentrated on the ideological aspects of France's works.

The emergence of new translations was driven by several impetuses. Firstly, Maxim Gorky's initiative to educate the population through works of art led to a large-scale edition of native and foreign books, most of which were newly translated. Owing to this and other factors translation was theoretically studied, and there appeared new books containing tips for translators and results of academic research. One of the outcomes was the development of the new school of literary translation in the USSR in the 1930s, the so-called "Kashkin school" (Gal' 2015: 255-340; Burak 2011: 104-105), which dictated new understanding of the process and reconsidering the norm.

The implication of these processes was a big corpus of new translations of foreign literature. Translators of the new school, the principles of which proved to be supported by theorists and translators later on, opposed the literal translation and searched for the balance between using natural Russian speech and preserving foreign realias and concepts. The translation could not

9 Hereafter translation from Russian is ours. 
NIKITINA, TULIAKOVA

be a substitute for the original but was aimed at creating the perfectly correct idea of it (Chukovsky 2014: 19); thus the audience who could not read the original text would have an impression of the text's authenticity. It demanded scrupulous work with the text, preceded by careful analysis of the original in order to understand the author's message in minute detail. However, as this approach required a lot of talent and hard work, conjointly with editors, the number of low-quality translations was still impressive (Gal' 2015: 129-257). Another fact that hindered translation was that since the 1930s the censorship concerning foreign literature and its translation aggravated (Safiullina, Platonov 243-244; Sherry 2010: 3-5), which also implied that wide discussions of translations were not particularly welcome (Tretyakova 2012: 274).

\section{Challenges for Russian translators}

When translating L'Étui de nacre one can face a number of challenges. The first one is certainly stylistic, as France's prose is concise and metaphoric at the same time. This idea was expressed by K. Loks, who wrote: "The very translation of France poses great difficulty due to his elegant simplicity and peculiarly 'French' speech. It is hardest for a translator to convey the specifics of this or that seemingly unimportant image" (Loks 1928: 143). The cycle is a combination of three different groups, or 'layers.' The first six texts are based on legends from the early Christianity, followed by four 'modern' stories, set in contemporary France, and the last seven stories are devoted to the French Revolution. The groups not only differ in their setting, their language varies considerably, too. While the first part demonstrates elements of stylization and poetic embellishment, the other two are more modern; while the first two parts are more epic in their narration, the last one tends to use a faster, more dramatic structure. These differences become especially important when L'Étui de nacre is translated and published as a cycle - in this case the Russian version should reflect the contrast, which is not always the case, especially as several translators usually complete the work.

Also, in trying to re-create the atmosphere of the 'ancient' novels, Russian translators often make France's text extremely bookish and old-fashioned: “так как он не чужа бым прозормивости ${ }^{10}$ [bookish]”; “Эти Аве Ауши ... испрашивами [obsolete] Ее всемогущего покровительства” (France 1909c: 6). On the other hand, in their attempts to keep the translation close

10 Hereafter words and phrases are highlighted by us. 
to the original, translators frequently produce structures which sound clumsy and unnatural in Russian: “Это бымо бы прекраснейшее состояние в мире, если бы обмаАающие им ели кажАый Аень” (France 1911: 25).

Secondly, a typical feature of L'Étui de nacre is the abundance of realias (personal, geographic names, historical events) as well as literary and historic allusions. These are often ignored or misinterpreted by translators. Thus, Pompée becomes Ptolemaeus (France 1958: 667), "un térébinthe” (France 1984: 878) can be “терпентин” (France 1936: 161), “фисташковое Аерево” (France 1911: 4) or “скипидарное дерево” (France 1906b: 3). Besides, the cycle contains numerous names of plants, mythic creatures, which could hardly be imagined by translators, and even less by the readers, which resulted in some texts' vagueness.

The third challenge lies in the extralinguistic area and is caused by the subject - religion, mysticism and politics, which influenced the translation both before and after the October Revolution. Thus, some parts of the text were omitted, while others underwent transformations. For example, several pre-revolutionary translations of Le Procurateur de Judée did not include the episode when Jesus drove merchants from the temple (France 1936), probably because there Jesus is referred to as "madman." Another example is a translation of "une Juive de Jérusalem" (France 1984: 889) as non-standard "иудеянка"11 instead of "иудейка"12 in the translation of 1958 (France 1958: 672), evidently done to avoid association with the painful Jewish subject.

Finally, it should be mentioned that L'Étui de nacre has two versions, however, translations which appeared after 1922 bore traces of impact of earlier translations. For example, in the ultimate version the story Le petit soldat de plomb was divided by France into two parts by extracting the embedded narrative (La Perquisition). It allowed him to highlight the thematic connection between Le Procurateur de Judée and Le petit soldat de plomb and thus to emphasize the topic of history and memory. Only in 1958 was this structure shown in translation, though the order was again transformed. The second version, besides, also included a number of changes, which were not always reflected in later translations.

11 a woman from Judea

12 a Jewish woman 


\section{Translations of the cycle as a whole}

As L'Étui de nacre is a cycle, it presumes a certain degree of unity among its parts. This unity covers both the semantics and the style of the book. The whole cycle develops a number of themes, the central ones being antinomy of love and death, the earthly and the heavenly, the individual's role in history and history's role in the life of an ordinary man. These themes permeate all the three parts, thus establishing their universal, eternal nature. At the same time, the narrative system of each part is unlike the other two. The ancient novellas depict the protagonists from the outside, balancing between the unquestionable truth of the legend and the mockery of stylization. The modern part exploits a complex system of narrators, thus playing with the reader's trust. The Revolutionary part is focused on the main personages, reporting their actions and reflecting their emotions, but never penetrating into their thoughts. Ideally, the cycle should be perceived as a whole; unfortunately, the translation of the whole cycle was infrequent. In most cases the novellas were published separately, often along with parts from France's other cycles, which led to misinterpreting the author's general message.

Altogether, the cycle has been translated twice, but the history of translations is a dramatic one. Firstly it was done by the Moscow translator from French, Yulia Bromley, in 1907. It was later (1929) edited by Benedikt Livshits, a famous St. Petersburg (Leningrad) poet and translator, who reviewed the style and made the text more modern, but the translation became less precise. Although the new edition of the cycle had been published by then, Livshits still used the initial version of 16 stories, choosing not to make any structural changes. The cycle was published without the name of the translator, which may suggest that Bromley had either been repressed or she had emigrated. This edition of L'Étui de nacre, actually the result of work of two different people, was the most available one for the Soviet reader, until Livshits himself was arrested in 1937 and executed in 1938. This raised the necessity for a new translation, which was especially high as France's 8-volume collection of works was published in 1957-58. Although by this time Livshits had been rehabilitated (1957), the new translation already existed.

Thus, the second translation of the whole cycle appeared in 1958 and was completed by Yakov Lesyuk and Nina Yakovleva. They took the modern version of 1922, but their work also lacked unity, as the two translators, who were dealing with different stories, evidently employed different approaches. It should also be noted, that even after the academic publication of the whole cycle translations of separate stories continued to appear (France 1959a; France 1959b). This shows that the cycle still was not perceived as a separate 
work in Russia, which can be explained by numerous cases when the stories from L'Étui de nacre were published separately or combined with other stories.

Two examples of such publications should be mentioned here.

The first one is Vera Koshevich's (translator from English and French) collection Записки добровольиа: Pассказы ('Notes by a Volunteer: Short Stories'). The volume appeared in 1915 as a reaction to the onset of the Great War and comprised the stories published in 1904 in the $11^{\text {th }}$ (one story) and in the $12^{\text {th }}$ issue of Pyccאas Mbıcıs ('Russian Thought'), which included as many as five novellas from the last part. The close succession of the stories makes it possible to perceive them as a whole. It is not unnatural that the eve of the first Russian revolution provoked the interest in the last part of France's cycle, devoted to a somehow similar event, especially as France, in this work, showed little enthusiasm concerning the French bourgeois revolution and the motives behind most actors' deeds and decisions.

The second case is the translation by a little known St. Petersburg translator from French An. Annensky. He published eight stories in 1909, and the edition was popular enough to reappear in 1911. Although traditionally the titles of the stories were the same or very similar in different publications, Annensky changed them. While France's titles are mostly nominal, pointing at the main characters or events of the story, Annensky suggests an interpretation; so, Amycus et Célestin turns into Фавн и святой ('The Faun and The Saint'), Leslie Wood into Загробная мюбовь ('Love after death'), Gestas into Кающийся ('Repentant') etc. At the same time he published the original titles in French in the subtitles of Перламутровый лареu: Восемь рассказов ('L'Étui de nacre: eight stories'), thus engaging in a peculiar dialogue with the French writer.

Unlike Koshevich, Annensky opted for particular stories from different parts of the cycle. It is obvious that the translator was attracted by the stories exploiting some dramatic change within a personage or those with an explicit conflict or opposition. Missing out half of the stories accounts for the decrease in historical allusions and heightens the "eventual" side of the volume.

\section{Translations of individual stories and translational strategies}

When analyzing the translations of separate novellas, several observations can be made. First of all, the challenges mentioned above are not always answered, and the translations demonstrate a number of mistakes and inaccuracies. These refer to the realias (which may be lost or mistranslated), the style (which becomes too elevated and solemn), the names and quotations. Apart 
NIKITINA, TULIAKOVA

from these errors, some inaccuracies have a more systemic nature and can be explained by the translation strategy chosen. They include:

1. Adding extra information. Sometimes translators, in an attempt to make the text closer to the reader, add detail or clarify France's position. Even though the French writer was painfully attentive to the historical context, this does not always satisfy translators. So, L. Aelius Lamia from Le Procurateur de Judée turns into Lucius Aelius Lamia (France 1901: 2) and is directly identified with a particular Roman patrician. Sometimes this trend can lead to the loss of irony which is inherent in the original. For instance, the conversation between Amycus and Célestin is based on the different understanding of the Divine; as both characters worship the resurrected God, they may as well mean different Gods, because they use pronoun Il, not the name. The translator's choice of the name Christ destroys this ambiguity (France 1909a; France 1958).

2. Russification. Different translators engage in different degrees and levels of Russification. This sometimes occurs on the grammatical level, e.g. through using syntactic parallelism: “И вышем после того из своей пещеры Целестин, и пошех в ближайшую часовню"13 (France 1909а, 423). Sometimes the lexical level is involved as obsolete words and forms (“чарочка," “гумно,” “возопими, мобзая землю” (France 1906а)), as well as colloquialisms (“кунсштюки” (France 1909b, 19)) are used.

3. Transformation of France's 'aphorisms.' Sometimes France's sentences seem difficult to be conveyed into another language without a loss of either rhythm or meaning. A translator, who has to change the words anyway, may sometimes lose the initial meaning. So, Celestin's thoughts "Le faune est un hymne de Dieu" (France 1984: 895) will turn either into the literal but rather unclear “Фавн - это песнь Господу"14 (France 1911: 22) or a more logical, but incorrect “и фавн служит на славу Божию”' (France 1907: 22).

4. Transformation of allusions. First of all, this applies to the biblical texts. When France refers to the Bible, a translator can either take the corresponding passage from the Russian Gospels, or translate the quotation using their own wording. Thus, “Heureux les simples, car ils verront Dieu!” (France 1984: 923), an allusion (not a citation) to the Beatitudes, can be translated as the biblical "нищие Аухом"16 (France 1907: 52), “чистые сердцем"17 (France

\footnotetext{
And out went Celestin from his cave, and headed to the nearest chapel.

14 A faun is a song for God.

15 ...even the faun serves to God's glory.

16 the poor in spirit

17 the pure in heart
} 
Translation of Anatole France's L'Étui de nacre in Russia

1958: 705), “кроткие сердцем"18 (France 1909d: 184), or alternatively as "скромные" (France 1909b), which is not found in the Russian version of the Beatitudes.

A reference to Solomon's Song of Songs "Ma bien-aimée est comme un jardin clos" (France 1984: 921) is also translated either with a corresponding Russian quotation from the Psaltery: “Запертый саА - сестра моя" (France 1959: 227), or by referring to traditions of Russian classical poetry: “Возмюбленная моя, как вертограА уеАиненный”21 (France 1929: 59).

\section{Translations of Le Procurateur de Judée and Le Jongleur de Notre-Dame}

We will now concentrate on the two stories which enjoyed the greatest attention of translators. Both of them belong to the 'ancient part' of the cycle and are based on well-known and popular plots. The stories, Le Procurateur de Judée and Le Jongleur de Notre-Dame, have been translated into Russian 16 times each. The reason for such popularity is subject to a thorough investigation, but the considerable bulk of material allows for highlighting the main tendencies in the Russian translations of the cycle.

Le Procurateur de Judée occupies the strong initial position in the cycle. Although it is set in ancient times, its plot and narrative structure are different from the rest of the ancient stories. While the latter are based on the legend, exploiting the motif of the miraculous, the former refers to the ancient genre of dialogue and stands out as realistic and full of historical realias. Justifying its position, Le Procurateur de Judée introduces the central themes of the whole cycle. It deals with the contrast between the man's private and political life, the meaning of history for a person and a person for the history. It also shows the human basic inability to understand anything which is outside their mind-set. The theme of love as the central reason for all human actions is also cautiously hinted at, as Lamia remembers a Judean woman (presumably Magdalene) who seems to have had a great effect on his life.

At the same time, Le Procurateur de Judée is one of the most ambiguous stories of the cycle - it means that the message is impossible to interpret in one and only way, unlike other stories, where the equality of opposite viewpoints

\footnotetext{
the meek

the modest

20 A garden locked up, my sister.

21 My beloved is like a solitary garden.
} 
NIKITINA, TULIAKOVA

is being established. The whole body of the text in which Pontius and Lamia are discussing history, religion, state, morals, and marriage, is intended to suddenly break at the point, Lamia's long prepared explicit mentioning of Christ and Pilate's unexpected and inexplicable answer to the question if he remembers Jesus.

II se faisait appeler Jésus le Nazaréen, et il fut mis en croix pour je ne sais quel crime. Pontius, te souvient-il de cet homme?...

Puis, après quelques instants de silence: Jésus? murmura-t-il, Jésus le Nazaréen? Je ne me rapeller pas (France 1984: 889-890).

After that the narrative stops, and no author's comment is available to help the reader decide if the protagonist is lying or telling the truth concerning his inability to recall this episode of his career.

Most translations seem to be unable to preserve this ambiguity of the point and choose one or the other interpretation. It is only natural that the translations done before the Revolution prefer to interpret Pilate's words as a lie.

- Помнишь ты Его, Понтий? 22

- Иисус, прошептам он: - Иисус из Назарета? Не помню. ${ }^{23}$ (France 1903: 67)

After the Revolution the mode changes, and the story is often published as one of the brightest examples of anti-religious propaganda.

После нескольких секунА молчания он произнес:

- Иисус? Иисус Назареянин? Нет, что-то не помню. ${ }^{24}$ (France 1959: 214)

So, the translators' choice directly influences the whole message of the story, as well as the understanding of the author's style.

Le Jongleur de Notre-Dame does not pose such a riddle as Le Procurateur de Judée, but presents certain difficulties for translation and interpretation. France turns to this old plot, well-established in the tradition. Unlike other 'ancient' novellas, which are based on either unknown or invented plots, Le Jongleur was quite familiar to the contemporary French reader; medieval

22 Do you remember Him, Pontius?

23 Jesus, - he whispered, Jesus of Nazareth? - I don't remember.

24 After several seconds of silence, he said, - Jesus? Jesus Nazarey? No, I don't think I remember. 
Translation of Anatole France's L'Étui de nacre in Russia

poem Le Tumbeor Nostre Dame was published in 1873 in Old French with comment from Gaston Paris and it inspired several poets and writers in Europe and the United States (Ziolkowsky 2006).

In Russia the story was hardly known to the reader and was perceived without a context. The lack of awareness of the context could lead to mistranslations. As France introduces a figure of a juggler, instead of a traditional tumbler, he suggests a seme of mockery and disrespect (Ziolkowsky 2006: 172), only to reject it later: "Il n'imitait pas les baladins larrons et mécréants, qui ont vendu leur âme au diable" (France 1984: 919). This meaning is preserved in some translations: “Он не следовам примеру плутоватых и нечестивых шутов, которые продали свою Аушу Аьяволу” 25 (France 1959: 225). However, other translators seem to misunderstand the author's message: “Он не подражам тем богохумьникам и безбожникам, которые продахи Аушу Аьяволу" 26 (France 1958: 701), in which case the character's choice has no motivation, and the whole passage seems rather vague.

France's story centres round the cult of the Virgin Mary, which is reminiscent of the chivalrous, romantic one. The image of Mary here symbolizes femininity, and the monks' desire to please her resembles romantic courting. If the traditional plot shows the juggler as an un-taught person who is ashamed of his own ignorance, France's Barnabé suffers not unlike a jealous lover, who cannot compete with his more attractive rivals.

The image of Mary is typical of the whole cycle. The image of L'Étui de nacre, through its cultural associations, may refer to the female. Historically, mother-of-pearl functioned as an attribute of both Venus and Mary. In antiquity it symbolized earthly beauty and love, while in Christianity it became a symbol of Immaculate Conception (Ohly 2002; Fricke 2012). All the female images in the cycle share this virginal eroticism. Most stories feature female characters who are both seductive and pure, passionate and religious. It is evident in the first part of L'Étui de nacre, where female saints can sometimes become flirty, in the second part, where a pious virgin turns out to have chosen the spiritual path because of the death of her lover, and in the third part, where the beautiful heroines reject sexuality for the sake of higher principles. The impossibility to fully unite with the beloved is both painful and inspiring for the male protagonists.

This motive differentiates France's interpretation of the juggler's story from previous texts, where he is perceived either as a pitiful creature who

25 He did not follow the example of cunning and unholy jesters, who have sold their soul to the devil.

${ }^{26}$ He did not imitate those blasphemers and atheists, who have sold their soul to the devil. 
NIKITINA, TULIAKOVA

deserves his reward, or as an unconventional artist who rises above the settled norms due to his natural talent (Ziolkowsky 2006: 163). In L'Étui de nacre Barnabé stands among other characters driven by the eternal and sacred femininity. This theme is sufficiently reduced in Russian translations, both before and after the Revolution. Translators predominantly change the tone to the respectful mode, thus diminishing the meaning of Mary's image as the symbol of femininity. For example, Barnabé addresses Mary in his prayers as Madame (France 1984: 919), while in most Russian publications his address is either neutral and traditional "царица небесная" “матерь Божия" 28 (France 1907: 47) or familiar "матушка"29 (France 1909с: 9), which completely changes the author's attitude.

The translations of Le Procurateur de Judée and Le Jongleur de NotreDame demonstrate a variety of translation strategies, approaches, aims - and mistakes. Ironically, among the sixteen versions of each story it is impossible to find an 'ideal' variant. On the contrary, the tendency is that later translations may become less subtle and fail to convey the author's message.

\section{Conclusion}

The history of Russian translation of L'Étui de nacre is truly exciting. Rarely is a work of prose translated into a foreign language so many times and under such different circumstances. The translations can illustrate not only the evolution of translation approaches and techniques, but the historical, cultural and stylistic changes that the country underwent during this period. Although they vary greatly in their epoch, status and quality, it is still possible to draw some general conclusions.

First of all, in most cases the translations were done independently from one another, so that later versions did not compensate for the mistakes and inaccuracies in the previous versions, but produced their own ones. Even the academic publications lacked profound research of the already existing variants.

Secondly, none of the translations could convey the meaning of the original as a cycle with a unified topic and imagery. It was partly due to the manner of publication, when parts of the cycle appeared separately. Even when they were gathered under one cover, little heed was paid to the unity of the cycle.

\footnotetext{
27 Queen of Heaven.

28 Mother of God.

29 My dearest mother.
} 
Translation of Anatole France's L'Étui de nacre in Russia

Finally, France's irony and ambiguity has been often lost along with his style. The writer's thorough re-creation of the epoch, attention to the detail, the aesthetic feeling towards objects suffered from the factual mistakes and careless research, while his ambivalent understanding of history and religion was sacrificed for the sake of ideology. Ironically, after dozens of translations, the real L'Étui de nacre still remains unknown to the general Russian public.

\author{
Natalia Nikitina \\ gromovanat@list.ru \\ Department of Foreign Languages \\ National Research University Higher School of Economics \\ 196143 СПб., пр. Юрия Гагарина, 36-182 \\ РОССИЯ / RUSSIA \\ Natalia Tuliakova \\ n_tuljakova@mail.ru \\ Department of Foreign Languages \\ National Research University Higher School of Economics \\ 199034 СПб., 18 миния В.О., 9-33 \\ РОССИЯ / RUSSIA
}

\title{
References
}

Bruysov, A. 1906. Anatole France. Tais. - Pereval, 2, 68-69.

Bruysov, A. 1907. Anatole France. Sad Epikura. - Pereval, 6, 54.

Burak, A. 2011. Soviet Legacy in the Envilening Russian Translations of American Fiction: Origins of Ozhivliazh - Vestnik Nizhegorodskogo gosudarstvennogo lingvisticheskogo universiteta im. N.A. Dobrolyubova, 13, 100-113.

Chukovsky, K. 2014. Vysokoe iskusstvo. Printsipy khudozhestvennogo perevoda. SanktPeterburg: Azbuka.

Fedorov, A.V. 1968. Osnovy obschey teorii perevoda (lingvistichesky ocherk). Moskva: Vysshaya shkola.

Fedorov, A.V. 1983. Iskusstvo perevoda i zhizn' literatury. Ocherki. Leningrad: Sovetsky pisatel'.

France, A. 1901. Prokurator Iudei. [V.K.] - Russkiye vedomosti, 01.04, 2-3.

France, A. 1903. Pravitel' Iudei. [V. Gorlenko] - A. France, Priznaniya skeptika $i$ rasskazy. Sankt-Peterburg, 47-67.

France, A. 1906a. Akrobat. [A. Gertsyk, E. Gertsyk] - A. France, Rasskazy. Moskva, 141-152.

France, A. 1906b. Prokurator Iudei. [Z. A. Vengerova] - Sankt-Peterbug: Malykh.

France, A. 1907. Perlamutrovy larchik. [Yu. Bromley]- Moskva: Tipografiya Lissnera. 
NIKITINA, TULIAKOVA

France, A. 1909a. Amikus i Tselestin. [Z. L'vovski] - Nedelya sovremennogo slova, 52, 423-424.

France, A. 1909b. Barnabe. [Z. L'vovski] - France, A., Mendes, K., Yakobsen, P.I. Rasskazy. Sankt-Peterburg, 19-28.

France, A. 1909c. Zhongler Bogomateri. [A. I. Kuprin] - A. France, Rasskazy. SanktPeterburg: Maksimov, 1-9.

France, A. 1909d. Zhongler Bogomateri. [V. F. Korsh] - A. France, Sobraniye sochinenii $v 12$ tt. Moskva, 1909. T. 6, 175-184.

France, A. 1911. Perlamutrovy larets. [A. Annensky] Sankt-Peterburg.

France, A. 1915. Zapiski doblovol'tsa. Rasskazy. [V. Koshevich] Moskva: Universitetskaya biblioteka.

France, A. 1929. Perlamutrovy larets - A. France, Polnoye sobraniye sochinenii v $20 \mathrm{tt}$. Moskva, Leningrad: Gos. izd-vo khud. lit-ry. T. 9, 9-170.

France, A. 1936. Prokurator Iudei. [M. V. Lind] - A. France, Skazki i rasskazy. Moskva, 160-175.

France, A. 1958. Perlamutovy larets. [N. G. Yakovleva, Ya. Z. Lesyuk] - A. France, Sobraniye sochinenii: $v 8$ tt. Moskva: Goslitizdat. T. 2, 657-806.

France, A. 1959a. Prokurator Iudei. [E. Linetskaya] - A. France, Izbrannye rasskazy. Leningrad: Lenizdat, 201-214.

France, A. 1959b. Zhongler bogmateri. [T. Khmel'nitskaya] - A. France, Izbrannye rasskazy. Leningrad: Lenizdat, 224-229.

France, A. 1984. L’Étui de nacre - A. France, Ouvres (4 vol.). Edition établie, présentée et annotée par Marie-Claire Bancquart. Paris: Gallimard, Bibliothèque de la Pléiade. T. 1, 875-1023.

Fricke, B. 2012. Matter and Meaning of Mother-of-Pearl: The Origins of Allegory in the Spheres of Things. - Gesta 2012, Vol. 51, Issue 1, 35-53.

Gal', N. 2015. Slovo zhivoe i mertvoe. Sankt-Peterburg: Azbuka.

Hofmann, V. 1910. Nasha perevodnaya literatura - Vestnik Evropy, Issue 3, 401-410.

Kuzmin, M.A. 1989. Stikhi i proza. Moskva: Sovremennik.

Loks, K.G. 1928. France - Pechat' i revolutsiya, issue 7, 141-143.

Ohly, F. 2002. Die Perle des Wortes: Zur Geschichte eines Bildes für Dichtung. Frankfurt: Insel.

Safiullina, N., Platonov, R. 2012. Literary Translation and Soviet Cultural Politics in the 1930s: The Role of the Journal 'Internacional'naja literatura' - Russian Literature, Vol. 72, Issue 2, 239-269.

Sherry, S. 2010. Censorship in Translation in the Soviet Union: The Manipulative Rewriting of Howard Fast's Novel 'The Passion of Sacco and Vanzetti' Slavonica, Vol. 16, 1, 1-14.

Sokolov, V.B. 1996. Entsiklopediya bulgakovskaya. Moskva: Lokid; Mif.

Tretyakova, E.A. 2012. Evolyutsiya otechestvennoy kritiki perevoda - Vestnik Chuvashskogo universiteta, 4, 270-275.

Voloshin, M.A. 1999. Iz literaturnogo naslediya. Sankt-Peterburg: Aleteya.

Zamyatin, E.M. 1988. Sochineniya. Moskva: Kniga.

Ziolkowski, J. 2006. Juggling the Middle Ages: The Reception of Our Lady's Tumbler and Le Jongleur de Notre-Dame - Studies in Medievalism, XV, 157-197. 